\title{
Japan modifies plans for plutonium in wake of protests over shipments
}

Tokyo. Growing international concern over Japan's plans to ship large amounts of weapons-grade plutonium from Europe has encouraged the head of Japan's most powerful organization for research and development of nuclear power to suggest a new form of nuclear fuel recycling, avoiding the production of pure plutonium that could be diverted to nuclear weapons.

Last week, the president of the Nuclear Fuel Development Corporation (PNC), a semigovernment organization affiliated with the Science and Technology Agency (STA), proposed at a symposium in Tokyo that Japan should consider operating future nuclear power stations on unpurified plutonium, not on pure weapons-grade plutonium derived from reprocessed nuclear fuel (see below). The idea would mark a drastic reorientation of Japan's research and development of nuclear power, but it faces many technical hurdles.

PNC's idea is much more than just a measure to limit proliferation of nuclear weapons. If implemented, it would separate the technology for nuclear fuel recycling from its origins in nuclear weapons.

PNC is probably Japan's richest government-supported research and development organization, receiving about $¥ 150$ billion (US $\$ 1.25$ billion) a year from STA, or more than a quarter of the agency's total budget and an additional $¥ 50$ billion from Japan’s electric utility companies. The money goes for development of new types of nuclear fuel and nuclear power stations, including the prototype fast breeder reactor Monju, which is expected to go critical early next year after having already cost $¥ 600$ billion.

Monju's appetite for plutonium is driving Japan's plans to start shipping tons of plutonium each year from reprocessing plants in France and Britain. But opponents argue that Japan already produces enough plutonium to meet Monju's needs. A Japanese freighter, the Akatsuki Maru, is on its way to
Cherbourg to pick up the first shipment of over one ton of plutonium derived from spent Japanese nuclear fuel reprocessed in France.

The planned shipment has provoked outcry from South Africa to Malaysia to the tiny Republic of Nauru, a 3-km-wide island in the middle of the Pacific Ocean. All are concerned that the ship might be involved in an accident or hijacking on their doorstep.

Officials in STA's Nuclear Fuel Division, trying to distance themselves from the PNC proposal, say that it is simply an "idea" put forward by the semi-government corporation. A PNC official says that STA is awaiting a debate next year by subcommittees of the Atomic Energy Commission on Japan's next five-year plan for development of nuclear power. But PNC is clearly committed to this drastic reappraisal of Japan's plutonium policy.

PNC's idea would require new technology to use crude plutonium in unpurified form mixed with highly radioactive material that is now removed in the reprocessing of nuclear fuel. Present thinking calls for burning of purified plutonium in yet-to-be developed commercial breeder reactors and advanced conventional reactors fuelled with mixed uranium and plutonium fuel. The unpurified fuel would be a less efficient fuel and would require sophisticated robot technology to handle material much more radioactive than pure plutonium and uranium. But it would reduce the amount of highlevel radioactive waste from nuclear power plants and could not easily be diverted into the production of nuclear weapons.

Japanese laws require nuclear power to be used only for peaceful purposes. Under its present constitution and international treaties, Japan cannot divert plutonium into production of nuclear weapons. But in less than 20 years the amount of pure plutonium in Japan, including imports from Europe and domestically produced plutonium, will

\section{How to handle hot plutonium}

Plutonium is extracted from spent nuclear fuel by dissolving fuel rods in nitric acid. Gases given off are collected or safely disposed of in the environment and the aqueous solution is then chemically treated to remove highly radioactive components. Disposal of this high-level radioactive waste remains a significant problem for governments and the nuclear power industry.

Japan's PNC has proposed that these highly radioactive materials need not be removed if robot technology can be developed to handle the material and form it, first, into pellets and then fuel rods. Once made into rods, the fuel could be used by existing nuclear power plants. The new technology would give these plants a second purpose apart from generating electricity: they would become facilities for the burning and reuse of high-level radioactive waste.

rise from a few to nearly 100 tons.

Nuclear weapons require the extraction of pure plutonium that, being only weakly radioactive, fits into a light bomb casing. Highly radioactive elements must therefore be removed in the production of plutonium. As a result, the nuclear power industry has not yet tried seriously to develop the technology to handle and manufacture this more radioactive material into fuel.

The PNC proposal is long-term. It has taken Japan 25 years to reach its present level of capability to produce pure plutonium. Development of the proposed new nuclear fuel recycling process would take at least ten to fifteen years and it will not affect facilities already close to operation, such as Monju and the huge Rokkasho nuclear fuel recycling facility under construction in northern Japan.

David Swinbanks

\section{Mail-order notification would replace permits for US field tests}

San Francisco. US biotechnology companies will be able to notify the government by mail of field tests of six major crops instead of waiting months for a formal permit under proposed regulations that could be announced this week. The new rules for field tests of genetically engineered organisms would apply to crops modified with specific genes to resist insects or disease or to tolerate stronger doses of certain herbicides.

For months, academics and members of the US Council on Competitiveness, which would prefer even fewer restrictions, have battled with an unusual alliance of environmentalists and the US biotechnology industry, which value continued review, over the contents of the proposed regulations. Earlier this week, the two sides met to settle their differences.

As written by the US Department of Agriculture (USDA), the regulations would exempt from the permit procedure crops and gene modifications already tested under the more than 340 permits issued for nearly 700 US sites over the past five years. Trials of tomatoes, corn, cotton, soybeans, potatoes and tobacco transformed using disarmed Agrobacterium tumefaciens, certain viruscoat protein genes, certain virus antisense genes and/or various noncoding regulatory DNA elements, could go forward after a simple notification. All field tests would have to comply with special management techniques, including destruction of the genetically altered plants in the field and moni- 